\title{
A Qualitative Study of Vocabulary Learning Strategies Applied by Iranian Undergraduate EFL Learners in Real Learning Setting
}

\author{
Mahdi Yazdi ${ }^{1} \&$ Reza Kafipour ${ }^{2}$ \\ ${ }^{1}$ Shiraz University of Medical Sciences, Shiraz, Iran \\ ${ }^{2}$ International Branch, Shiraz University of Medical Sciences, Shiraz, Iran \\ Correspondence: Reza kafipour, International Branch, Shiraz University of Medical Sciences, Shiraz, Iran. Tel: \\ 98-917-315-8394. E-mail: rezakafipour@gmail.com
}

\author{
Received: February 12, 2014 Accepted: May 4, 2014 Online Published: June 13, 2014 \\ doi:10.5539/elt.v7n7p1 URL: http://dx.doi.org/10.5539/elt.v7n7p1
}

\begin{abstract}
This study tries to investigate real use of vocabulary learning strategies by Iranian EFL learners. To achieve this goal, the researcher applied a pure qualitative research method in which frequency of all strategies counted and then classified. To select participants for the current study, the researcher used cluster sampling and fish ball approach to select participants. Through this sampling procedure, 238 students were selected as the random samples. They were asked to write journals for six weeks based on what they did daily in vocabulary learning. Transcribing and analyzing the written journals revealed the most frequently used strategies as memory, determination, cognitive, metacognitive and social strategies respectively. Moreover, one cognitive strategy (make list of new words) and one metacognitive strategies (use English language media) were found as the most frequently used strategies when investigating sub-categories while one of metacognitive strategies (pay attention to English words when somebody is speaking English) and one of social strategies (ask teacher to check my definition) were identified as the least frequently used strategies.
\end{abstract}

Keywords: vocabulary learning strategies, EFL learners, second language, qualitative

\section{Introduction}

The world experienced different radical changes during the last three decades. These changes covers a wide area ranging from political changes to technological, social, and cultural ones. These changes lead people to new needs to be able to be adapted to new condition. One of the most significant needs which have been generated due to these changes is language learning and teaching. There is no doubt that second or foreign language plays an important role in today's world and affects people's lives. Because of numerous reasons such as studying at an English medium university or living in a foreign country, people all over the world are trying to learn English as a second or even a third language. In this respect, vocabulary knowledge plays a pivotal role in language learning proficiency. Although many attempts have been made to improve and enhance language learning, the real achievement has not been satisfactory and convincing (Sahbazian, 2004). It may be due to different reasons. One of the reasons may be differences among individuals such as differences, in social class, attitude, gender, aptitude, culture and motivation (Oxford, 2001). Another reason may be this point that no universal method or techniques can be found for language learning and teaching. Therefore, the methods and techniques which work for one learner may not work for another one. Moreover, one method or technique which works for one learner in a specific condition and setting may not work for the same learner in another condition or different setting. This statement is consistent with what Grenfell and Harris (1999) said, "Methodology alone can never be a solution to language learning rather it is an aid and suggestion" (p. 10).

In Iranian universities vocabulary is partly ignored. It does not receive appropriate attention in curriculum and usually left to the students to be learnt (Kafipour, 2010). Vocabulary instruction is mainly incidental that is when the learners encounter new word, they are advised to look up dictionary to find the meaning. Dictionary definition and looking up dictionaries is dominant technique in finding the meaning of new words (Kafipour, 2010). 


\subsection{Objectives}

Based on what was said before, unlike most of the studies done so far which tried to investigate the perception of the learners toward the application of vocabulary learning strategies through the use of vocabulary learning strategies questionnaires, the current study is going to investigate the application of these strategies by Iranian EFL learners in real world through the use of journal writing.

\subsection{Research Question}

What are vocabularies learning strategies applied by Iranian EFL learners in daily English language learning?

\section{Literature Review}

Language learning strategies have attracted much attention in recent studies (Cohen, 1998; Chamot, 1987; O'Malley \& Chamot, 1990; Oxford, 1990) especially when the learner-centered approach has been increasingly adopted in the school curriculum. In this approach, the students participate actively in language learning activities; therefore, they should not remain passive (Oxford, 2001). A great deal of literature has linked learning strategies with self-direction in language learning, directly or indirectly, when discussing the significance of learning strategies and strategy instruction. First, learning strategies are the techniques used by language learners consciously to remove barriers in their learning process and to arrange their knowledge in a systematic order (Cohen, 1998; McDonough, 1999; O’Malley \& Chamot, 1990). A good language learner can use strategies flexibly, independently and appropriately (Oxford, 1990), and as such, Teaching Strategies could help learners to achieve autonomous learning (Benson, 2001; Benson \& Lor, 1998; Chamot \& Rubin, 1994; Nunan, 1996; Sinclair, 1999; Wenden, 2002).

These circumstances led researchers to shift their attention from teaching methodology to the learners himself/herself and the factors which may influence learners' learning process. Surveying language learning strategies is the outcome of this shift among the researchers. They studied language learning strategies along with other factors such as gender, aptitude, motivation, learning styles and etc (Sahbazian, 2004).

In teaching and learning vocabulary, vocabulary learning strategies are even more important in second language (L2) learning situations (Ahmed, 1989; Schmitt, 1997; Kojic-Sabo \& Lightbown, 1999). Vocabulary learning strategies (VLS) as the variable of this study is a branch of language learning strategies. Since the late 1970s, researchers noticed the importance of vocabulary learning strategies and these strategies received a special attention in research. Thorough research on vocabulary learning strategies boosted the researchers' knowledge on language learning process. According to Nation (2001), learners should be able to choose from among available vocabulary learning strategies. Moreover, learning these strategies occur through different steps. He continued that using vocabulary learning strategies needs knowledge obtained through learning. The use of these strategies will improve and enhance vocabulary learning.

Schmitt $(1997,2000)$ designed a taxonomy for vocabulary learning strategies which was distinct from that of other researchers. He divided strategies into two general categories including discovery and consolidation strategies. Discovery strategies consists of the strategies applied by learners to find the meaning of new words when they see the word for the first time while consolidation strategies are those strategies applied by learners when they see the word again. Determination and social strategies are in the category of discovery while social, memory, cognitive, and metacognitive strategies are classified under consolidation strategies. The strategies Schmitt classified under discovery and consolidation counts 58 individual strategies in total.

Schmitt designed his taxonomy with special reference to Oxford's (1990) classification of language learning strategies. Schmitt (2000) stated that his taxonomy is an amalgamation of all available classifications. He tried to combine all classifications proposed by other researchers to make the most comprehensible taxonomy. This classification system was adopted for the current study

For the present study, the classification presented by Schmitt $(1997,2000)$ will be used. The reason for selecting this categorization system is based on its wide coverage of different strategies. Moreover, Schmitt added new strategies to previous available categorization systems as Oxford (1990) and Chamot's (1987) categorization system. Thus, it is more complete and comprehensive than all other available categories of vocabulary learning strategies.

\section{Methodology}

\subsection{Research Design}

This study is a pure qualitative study. Qualitative method is used when the researchers are going to study human behavior and behavior changes. Therefore, the researcher tried to collect data qualitatively to ensure it is what 
the learners really do in vocabulary learning process

\subsection{Population and Sample}

The study was done in Semnan state in Iran which has been chosen based on random cluster sampling out of 31 available clusters. Thus, each province received a number. Then, one out of 31 was selected randomly (Fishball procedure). The number associated with Semnan province was selected randomly and this province determined as cluster for this study.

238 EFL undergraduate students at Semnan Universities were included in the study. The sample was selected from among 650 undergraduate EFL students which represented the sample of the population of the study based on the Krejcie and Morgan's sample size table. These students constituted a cluster from 5 universities in Semnan. A pool of student numbers in these 5 universities was built up. Then, 238 student numbers were randomly drawn.

\subsection{Instrument}

Different instruments and procedures have been used for data collection in language learning researches, such as questionnaires, interviews, tests, observations, think-alouds and diary use (e.g. Daly 1997; Drever 1995; Gu \& Johnson, 1996; Harrison, 1983; Horwitz, 1987; Nunan, 1992; Naiman et al., 1996; Nakamura, 2000; Oxford, 1990; Read, 1997; Sakui \& Gaies, 1999; Seliger \& Shohamy, 1989; Swetnam, 1998). Guided by the theoretical consideration of fieldwork methodology, and in the light of considerations which will be discussed below, journal writing was employed in the present study.

There are four types of qualitative data collection procedures which are observations, interviews, documents and audiovisual materials (Creswell, 2008). Journal writing or personal journal is a technique through which information about the routines and activities of participants when studying a specific course can be elicited. Since this study is seeking for the stream of participants' thoughts in their language and words, journal writing is chosen as another instrument. In comparison with other instruments such as interview that needs to be recorded and transcribed data, journal writing can be easily analyzed and interpreted and is less time-consuming. In journal writing, the learners are not limited to a set of options and items to choose from, but they can report freely everything that happens daily. Nunan (1992) believes that the data obtained through journals is unique and such data cannot be collected through other data collection instruments and procedures. He continued that the data collected through journal writing is based on daily activities, so the data is real representative of what learners do in real world while the data obtained through questionnaire may be based on perception or ideality and not reality.

\subsection{Procedure}

The students were asked to record all activities they do daily in the process of language learning and specially vocabulary learning for 6 weeks. It is worth mentioning that the students submitted their journals daily, so they could be asked to clarify what they had written the previous day if some unclear points were found in their journal. In this way, the researcher ensured that he received the most complete form of journals. After getting the journals, they were transcribed and themes were extracted from the data. Themes were classified according to Schmitt's (1997-2000) classification of vocabulary learning strategies.

\section{Results and Discussion}

Table 1. Descriptive statistics for different categories of vocabulary learning strategies

\begin{tabular}{lllllll}
\hline Strategies & Memory & Determination & Cognitive & Metacognitive & Social & Total \\
\hline Number & 188 & 155 & 113 & 96 & 48 & 600 \\
Rank & 1 & 2 & 3 & 4 & 5 & 6 \\
\hline
\end{tabular}

According to Table 1, the most frequently used strategy was memory strategy which was applied by the participants 188 times while social strategy was identified as the least frequently used strategy which was used 48 times. Table 2 summarizes the frequency of use of sub-categories of all five different strategies. 
Table 2. Frequency of individual strategies

\begin{tabular}{llllllllll}
\hline Memory & $\mathrm{C} 1=33$ & $\mathrm{C} 2=27$ & $\mathrm{C} 3=31$ & $\mathrm{C} 4=11$ & $\mathrm{C} 5=24$ & $\mathrm{C} 6=15$ & $\mathrm{C} 7=21$ & $\mathrm{C} 8=22$ & $\mathrm{C} 9=4$ \\
Determination & $\mathrm{A} 1=22$ & $\mathrm{~A} 2=17$ & $\mathrm{~A} 3=18$ & $\mathrm{~A} 4=27$ & $\mathrm{~A} 5=14$ & $\mathrm{~A} 6=32$ & A7 $=29$ & & \\
Cognitive & $\mathrm{D} 1=4$ & $\mathrm{D} 2=22$ & $\mathrm{D} 3=37$ & $\mathrm{D} 4=9$ & $\mathrm{D} 5=17$ & $\mathrm{D} 6=8$ & $\mathrm{D} 7=7$ & $\mathrm{D} 8=2$ & D9 $=6$ \\
Metacognitive & $\mathrm{E} 1=37$ & $\mathrm{E} 2=30$ & $\mathrm{E} 3=1$ & $\mathrm{E} 4=28$ & & & & & \\
Social & $\mathrm{B} 1=8$ & $\mathrm{~B} 2=18$ & $\mathrm{~B} 3=12$ & $\mathrm{~B} 4=1$ & $\mathrm{~B} 5=10$ & & & & \\
\hline
\end{tabular}

Note: Refer to appendix for full strategy name of the codes used in this table

According to Table 2, C3 (connect word to its synonym and antonym $=31$ times) and $\mathrm{C} 1$ (connect word to an animated/inanimate object $=33$ times) were the most frequently used memory strategies while C9 (study the word's part of speech $=4$ times) and C4 (draw a picture of word $=11$ times) were the least frequently used memory strategies. Having a physical image or representation for the words and especially abstract words is an effective technique to learn and retain new words (Nation, 2001). This may be the reason why the respondents preferred connecting new words to animate and inanimate objects. High application of C3 strategy may be due to the teaching methods in Iranian high schools and universities. It is common to ask students to use antonym and synonym dictionaries. Therefore, the learners become familiar with this strategy and are forced to use it in their English vocabulary learning.

The second most frequently used vocabulary learning strategy according to the journals written by the respondents was determination strategy. According to Table 2, A6 (using monolingual dictionary $=32$ times) and A7 (using bilingual dictionary $=29$ times) were the most frequently used strategies among determination strategies while A5 (analyzing pictures and gestures $=14$ times) and A2 (analyzing parts of speech $=17$ times) were found to be the least frequently used strategies by the respondents. These findings showed that the respondents preferred the simplest and most direct way of finding the meaning of new words that is using dictionaries whether bilingual or monolingual.

The third type of vocabulary learning strategy in Schmitt's classification system is cognitive strategy. Instances of eight cognitive strategies in Schmitt's classification system as well as one cognitive strategy not included in Schmitt's classification system were found in the journals written by the respondents. the most frequently used cognitive strategies were D2 (keeping a vocabulary notebook $=22$ times) and D3 (verbal repetition $=37$ times) while the least frequently used strategies were D8 (use vocabulary section in text book $=2$ times) and D1 (using flash cards $=4$ times). It was expected to find out keeping a vocabulary notebook as the most frequently used cognitive strategy since the students become familiar with this strategy from the first year of Junior high school. To encourage the students to use this strategy, the teacher can ask them to prepare a note book and record new words in. Moreover, the students are asked to repeat the words verbally in the classroom in every session on a regular basis.

Using flash cards was found to be the least frequently used strategy while it was proved as an effective vocabulary learning strategy in most of the studies (Nation, 2001; Fan, 2003; Kafipour, 2010). The possible reason may be unfamiliarity with this strategy or considering it as useless to make flash cards. One of the respondent stated that he rejected using and making flash cards since it is time-consuming.

The next category of vocabulary learning strategies is metacognitive strategy. As Table 4.14 showed, E1 (skip new words $=37$ times) was the most frequently used strategy while E3 (test oneself by word test $=1$ time) was applied only once and was the least frequently used strategy. This finding showed that the respondents preferred to skip new words whenever it would not affect their comprehension. Thus, the respondents were fully aware of this strategy. This finding is different from the findings of another study (Kafipour, 2010) in which the subjects considered this strategy as a negative action in the process of learning a new language. Moreover, this finding that the respondents used self-assessment only once is congruent with the finding of another research done by Kafipour (2010). He also found it among the least frequently used strategies in qualitative phase of his study and reported some evidences based on the writings of the subjects why they did not used this type of strategy. Some of his subjects reported that it may lead to more stress as one of his interviewees said in the following sentence:

If I find that I have not learned new words fully, I will be frustrated and cannot continue studying more; therefore, I try not to test myself and focus on studying.

The last type of vocabulary learning strategies according to Schmitt's classification system is social strategy. As 
depicted in Table 4.15, B2 ask teacher for paraphrase or synonyms (18 times) was the most frequently used social strategy by the respondents. It appears that the respondents consider teacher as the most reliable source of knowledge and try to ask questions from the teacher. This finding is similar to the findings of studies done by Kafipour (2010) and Shahbazi (2004).

However, B4 (ask teacher for L1 translation) was used only once by one of the respondents with low vocabulary knowledge. It is expected to see more instances of this strategy especially by respondents with low vocabulary knowledge since those who have an insufficient vocabulary pool try to compensate it by resorting to their mother language in the process of language learning (Schmitt, 2000). However, it was used only once. The reason behind may be due to the classroom rules imposed by the teacher. The rule says, 'no Persian allowed in the classroom'. This reason clearly stated by the only respondents who reported the use of this strategy. This could also justify why this strategy was the least frequently used strategy by two groups of respondents.

\section{Conclusion}

This study also investigated the most and least frequently used strategy. Memory strategy was the most frequently and cognitive strategy was the least frequently used strategy. It proved that Iranian junior EFL students in the current study preferred direct strategies which are simple strategies with lowest mental activities required. As was explained in the discussion section, this result might be due to a teacher-centered environment in Iran where the teacher is responsible to provide all relevant information to the students through lectures and presentations and the students just listen and take notes. The next strategies in accordance with the highest frequency of use were found to be metacognitive, social and determination strategies. Unlike memory strategy, cognitive strategy needs more deep processing and mental activities which might justify why cognitive strategy was the least frequently used strategy. It may be improved if the instructor provides specific exercises for cognitive strategies and ask the students to do them daily.

Although the curriculum in Iran claimed that the instruction system was based on the communicative approach, the results of research showed that student still tended to use grammar translation methods and rote learning since they mostly preferred strategies such as repetition, whether oral or written. Therefore, by taking practical actions and steps to introduce the indications of communicative approach such as making students familiar with social strategy and cognitive strategy. This can be done by direct instruction of these types of strategies by providing definition of strategies, the situation in which each strategy can be used, the method of correct application of each strategies and finally providing some exercises to practice the use of each strategy. Teachers could enhance English language proficiency/learning in students by giving them the opportunity to use wider range and probably more effective strategies.

\section{References}

Ahmed, M. O. (1989). Vocabulary learning strategies. In P. Meara (Ed.), Beyond Words (pp. 3-14). London: CILT.

Benson, P. (2001). Teaching and researching: Autonomy in language learning. London: Longman.

Benson, P., \& Lor, W. (1998). Making sense of autonomous language learning. English Centre Monograph, no. 2: The University of Hong Kong.

Chamot, A. U. (1987). The learning strategies of ESL students. In A. Wenden, \& J. Rubin (Eds.), Learner strategies in language learning (pp. 71-84). Cambridge: Cambridge University Press.

Chamot, A. U., \& Rubin, J. (1994). Comments on Janie Rees-Miller's “A critical appraisal of learner training: Theoretical bases and teaching implications": Two readers react. TEOSOL Quarterly, 28(4), 771-776. http://dx.doi.org/10.2307/3587559

Cohen, A. D. (1998). Strategies in learning and using a second language. London: Longman.

Creswell, J. W. (2008). Educational research: Planning, conducting, and evaluating quantitative and qualitative research. New Jersey: Pearson Education, Inc., Upper Saddle River, New Jersey.

Daly, P. (1997). Vocabulary learning strategies in the formal and informal linguistic environment (Unpublished MA thesis). University College Cork, Cork, Irland.

Drever, E. (1995). Using semi-structured interviews in small-scale research: A teacher's guide. Glasgow: Scottish Council for Research in Education.

Grenfell, M., \& Harris, V. (1999). Modern languages and language learning strategies: In theory and practice. London: Routledge. 
Gu, Y., \& Johnson, R. K. (1996). Vocabulary learning strategies and language learning outcomes. Language Learning, 46(4), 643-679. http://dx.doi.org/10.1111/j.1467-1770.1996.tb01355.x

Harrison, A. (1983). A language testing handbook. London \& Basingstoke: Macmillan Press Ltd.

Horwitz, E. K. (1987). Surveying Student Beliefs about Language Learning. In A. Wenden, \& J. Rubin (Eds.), Learner Strategies in Language Learning (pp. 119-132). New York, London, Toronto, Sydney, Tokyo, Singapore: Prentice Hall.

Kafipour, R. (2010). Vocabulary learning strategies, vocabulary knowledge and reading comprehension of EFL undergraduate students in Iran (Unpublished doctoral dissertation). University Putra Malaysia, Malaysia.

Kojic-Sabo, I., \& Lightbown, P. M. (1999). Students' approaches to vocabulary learning and their relationship to success. The Modern Language Journal, 83(2), 176-192. http://dx.doi.org/10.1111/0026-7902.00014

McDonough, S. H. (1999). Learner strategies. Language Teaching, 32, 1-18. http://dx.doi.org/10.1017/S0261444800013574

Naiman, N., Frohlich, M., \& Todesco, A. (1996). The good language learner. Clevedon, Philadelphia, Adelaide: Multilingual Matters Ltd.

Nakamura, T. (2000). The use of vocabulary learning strategies: The Case of Japanese EFL Learners in Two Different Learning Environments (Unpublished PhD thesis). University of Essex, Essex, United Kingdom.

Nunan, D. (1992). Research methods in language learning. Cambridge: Cambridge University Press.

Nunan, D. (1996). Towards autonomous learning: Some theoretical, empirical and practical issues. In R. Pemberton, E. S. L. Li, \& H. D. Pierson (Eds.), Taking Control-Autonomy in Language Teaching (pp. 13-26). Hong Kong: Hong Kong University Press.

O’Malley, J., \& Chamot, A. (1990). Learning strategies in second language acquisition. Cambridge: Cambridge University Press. http://dx.doi.org/10.1017/CBO9781139524490

Oxford, R. (1990). Language learning strategies: What every teacher should know. Boston: Newbury House.

Oxford, R. (2001). Language learning strategies. In R. Carter, \& D. Nunan (Eds.), The Cambridge Guide to Teaching English to Speakers of Other Languages (pp. 166-171). Cambridge: Cambridge University Press. http://dx.doi.org/10.1017/CBO9780511667206.025

Read, J. (1997). Vocabulary and testing. In N. Schmitt, \& M. McCarthy (Eds.), Vocabulary: Description, acquisition and pedagogy (pp. 303-320). Cambridge: Cambridge University Press.

Sahbazian, S. (2004). Perceived vocabulary learning strategies of Turkish university students (Unpublished PhD thesis). Oklahoma State University, Oklahoma, USA.

Sakui, K., \& Gaies, S. J. (1999). Investigating Japanese learners' beliefs about language learning. System, 27(4), 473-492. http://dx.doi.org/10.1016/S0346-251X(99)00046-9

Schmitt, N. (1997). Vocabulary learning strategies. In N. Schmitt, \& M. McCarthy (Eds.), Vocabulary: Description, acquisition and pedagogy (pp. 199-227). Cambridge: Cambridge University Press.

Schmitt, N. (2000). Vocabulary in language teaching. New York: Cambridge University Press.

Seliger, H. W., \& Shohamy, E. (1989). Second language research methods. Oxford: Oxford University Press.

Sinclair, B. (1999). Survey review: Recent publications on autonomy in language learning. ELT Journal, 53, 309-329. http://dx.doi.org/10.1093/elt/53.4.309

Swetnam, D. (1998). Writing your dissertation. How to plan, prepare and present your work successfully. Oxford: How to Books.

Wenden, A. (2002). Learner development in language learning. Applied Linguistics, 23, 32-55. http://dx.doi.org/10.1093/applin/23.1.32

\section{Appendix}

Code list for all strategies found in the students' journals

A1. Check if the word is also a Persian word (machine)

A2. Check new word's from (verb, noun etc.)

A3. Guess from context 
A4. Look for any word parts that I know (impossible, colorful)

A5. Use any pictures or gestures to help me guess

A6. Use an English-English dictionary

A7. Use an English-Persian dictionary

B1. Ask the teacher to give me the definition or a sentence

B2. Ask my classmates for the meaning

B3. Study the word with my classmates

B4. Ask the teacher to check my definition

B5. Talk with native speakers

$\mathrm{C} 1$. Draw a picture of the word to help remember it

C2. Make a mental image of the word's meaning

C3. Connect the word to a personal experience

C4. Remember the words that follow or precede the new word

C5. Connect the word to other words with similar or opposite meanings

C6. Remember the words in 'scales' (always-often-sometimes-never)

C7. Group words together to study them

C8. Use new words in sentences

C9. Write paragraphs using several new words

C10. Study the spelling of a word

C11. Study the sound of a word

C12. Say the new words aloud when I first meet them

C13. Make a mental image of the word's form

C14. Remember the word using its part (im-, un-, -able, -ful, -ment, ex-)

C15. Remember the word using its word from (verb, noun, adjective)

C16. Make my own definition for the word

C17. Use physical action when learning a word

D1. Repeat the words aloud many times

D2. Write the words many times

D3. Make lists of new words

D4. Use flashcards to record new words

D5. Take notes or highlight new words in class

D6. Put English labels on physical objects

D7. Keep a vocabulary notebook

E1. Use English-language media (songs, movies, the internet)

E2. Test my with word tests

E3. Pay attention to English words when someone is speaking English

E4. Skip the new word

E5. Study new words many times

\section{Copyrights}

Copyright for this article is retained by the author(s), with first publication rights granted to the journal.

This is an open-access article distributed under the terms and conditions of the Creative Commons Attribution license (http://creativecommons.org/licenses/by/3.0/). 